\title{
Allocative Efficiency of Smallholder Cocoyam Farmers in South-South, Nigeria
}

\author{
Wilcox G. I. ${ }^{1}$, Ugwumba C. O. A. ${ }^{2}$, Achike A. I. ${ }^{3}$, Agbagwaa C. ${ }^{4}$, Uche F.B. ${ }^{5}$ \\ ${ }^{1,4}$ Department of Agricultural Science, Ignatius Ajuru University of Education, Rumuolumeni, Rivers State, Nigeria \\ ${ }^{2}$ Anambra State University, Igbariam Campus, Anambra State, Nigeria \\ ${ }^{3}$ University of Nigeria, Nsukka, Nigeria \\ ${ }^{4}$ Port Harcourt Polytechnique, Port Harcourt.
}

\begin{abstract}
The study examined the levels of allocative efficiency, socio-economic determinants of allocative efficiency and constraints to cocoyam production among smallholder farmers in South-South Nigeria. Multistage, purposive and random sampling techniques were used to select 200 cocoyam (100- Colocasia and 100Xanthosoma spp.) farmers for the study. Primary data were collected using structured questionnaire administered by personal interview. Descriptive and Parametric statistics involving Cobb-Douglas stochastic frontier cost function was used for data analyses using the maximum likelihood method. Results of the analyses indicated that majority (69\%) of the farmers were females; $78 \%$ attained some level of formal education and 45\% operated between 0.1-0.6 hactares of land. The Colocasia and Xanthosoma spp. farmers showed varying levels of allocative efficiency with no farmer attaining $100 \%$ allocative efficiency level. The mean, minimum and maximum efficiency levels for the two varieties were; $0.56,0.31$ and 0.86 and then 0.42, 0.22 and 0.82 respectively. The maximum likelihood estimates for the cost factors were positive and statistically significant for both varieties of cocoyam while the significant gamma $(\gamma)$ values of 0.63 and 0.51 establishes the fact that inefficiency exists among the sampled farmers. The determinants of allocative efficiency were farming experience, age and household size. Allocative efficiency can be improved for cocoyam (Colocasia and Xanthosoma spp.) through cost savings of $39.5 \%$ and $73.4 \%$ for the efficient and inefficient farmers. The major constraints to cocoyam production in the area were scarcity of improved high yielding corms, lack of capital, high cost of labour, high cost of transportation, lack of storage facilities, diseases and pests. It is therefore recommended that farmers should cut down on some of the cost incurring variables like labour and corms for planting through optimizing the use of family labour and growing the corms needed for future planting season. Again, since the ages of cocoyam farmers and farming experience were very significant in the production of cocoyam, it is recommended that the extension agents
\end{abstract}

organize seminars in the Local Government Areas and State levels were young and upcoming entrepreneurs can be trained and educated by the older farmers in order to exhibit higher levels of entrepreneurial capabilities and efficiency leading to higher farm output.

Keywords-Allocative efficiency, Stochastic Frontier cost function, Cocoyam production, South-South.

\section{INTRODUCTION}

The optimal use of resources by farmers in the production of food crops at least cost in order to maximize profit is a challenge farmers in Sub Saharan Africa are faced with. Nigeria, is not left out in this challenge because studies have shown that majority of the farmers are resourcepoor, cultivating on land holdings that range from 0.1 ha to 4.9 ha (Food and Agricultural Organization (FAO), 1990). These smallholder resource-poor farmers constitute about $70 \%$ of the farming population in Nigeria (Njoku and Olomola, 2011) growing root and tuber crops as base crops (Adebosin et al., 2011). Cocoyam (Colocasia and Xanthosoma spp) is one of the major root and tubers produced in large quantities in Nigeria (Ugbajah, 2013). It is grown in the tropics and subtropical regions of the world particularly in Africa for human nutrition, animal feed, and cash income for both farmers and traders (Onwubuya and Ajani, 2012). It ranks third in importance after cassava and yam among the root and tuber crops cultivated and consumed in Nigeria (Echebiri, 2004; Okoye, Asomugha, Okeke, Tanko and Onyeweaku, 2008). Colocasia and Xanthosoma spp. play very important roles in the livelihood of rural farmers, who often resort to cocoyam as an alternative source of their daily calories. Cocoyam on a global scale is ranked 14th as a root and tuber crop (Adelekan, 2012), going by annual production figures of 10 million tonnes (FAO, 2005). Nigeria is currently the world's leading producer of cocoyam (Okoye et al., 2009) accounting for up to 3.4 million metric tonnes annually.

Nutritionally, cocoyam is superior to cassava and yam in the possession of higher protein, mineral, vitamin contents and the starch is also more readily digested 
(Onyeka, 2014). It can be processed into cocoyam flour, can be consumed in various forms when boiled, fried, pounded or roasted and can also be processed into chips which have a longer shelf life (Ozor, 2013). The leaves are used as vegetables in preparing soup in various parts of the world (Asadu, 2006). It is highly recommended for diabetic patients, the aged, and children with allergy and for other persons with intestinal disorders (Onwubuya and Ajani, 2012), while the leaves are good source of folic acid, vitamin C, riboflavin and vitamin A (Ozor, 2013).

The average yield per land area has remained relatively low, ranging between 5 and $7.5 \mathrm{t} / \mathrm{ha}$ in Nigeria (Onyeka, 2014), far below the obtainable yield in China and Egypt. In South-South Nigeria, cocoyam production, marketing and consumption are interwoven enterprises that sustain many rural dwellers. As a result of this, cocoyam farming, production and sale contribute substantially to the economy of rural households. Production efficiency means the attainment of production goals without waste. Efficiency is often used synonymously with that of productivity which relates output to input. In agriculture the analysis of efficiency is generally associated with the possibility of farm production to attain optimal level of output from a given bundle of input at least cost (Ajao, Ogunniyi and Adepoju, 2012). It is not surprising that considerable effort has been devoted to the analysis of farm level efficiency in developing countries including Nigeria. An underlining premises behind this work is that farmers are not making efficient use of existing input resources and then efforts designed to improve efficiency would be more cost effective than introducing new technologies as a means of increasing agricultural output (Bifarin et al., 2010).

The objectives of the study were to: identify the farmers socio-economic characteristics, measure the levels of farmers' allocative efficiency and ascertain the determinants of allocative efficiency on two varieties of cocoyam- Colocasia and Xanthosoma spp. and the constraints to cocoyam production. The stated hypotheses were:

i. There is no significant difference in the allocative efficiency levels of farmers of Colocasia and Xanthosoma spp. and

ii. Allocative efficiency levels attained by farmers of Colocasia and Xanthosoma spp. are not significantly influenced by their socio-economic factors namely farmers' farming experience, education, age, household size and extension visit.

\section{METHODOLOGY}

The study was conducted in South-South, Nigeria. The climate is essentially tropical and humid with an average rainfall of $220 \mathrm{~mm}-250 \mathrm{~mm}$ (evenly distributed through its long wet season), which covers a period of eight months (March - October) and the dry season spanning the months of November to March (Edoumiekumo et al., 2014). Cocoyam (taro) is grown as a sole crop and sometimes in combination with other crops due to the subsistence nature of farming. It is one of the major root crops in the South-South States and plays an important role in the diet, health, economic and cultural (traditional) life of some people (Ajie, Chidibelu and Achike, 2015). The commonly grown types that are edible are the Colocasia esculenta and Xanthosoma saggitifolium.

Multistage, purposive and random sampling methods were used to select 200 (100- Colocasia and 100Xanthosoma spp.) respondents used for the study. Data on the socio-economic variables of the respondents such as age, gender, household size, marital status, educational level, source of income, farming experience, contact with extension agents, available storage facilities; production variables such as farm size, material inputs, labour supply and use, output of cocoyam with their current market prices and cocoyam production constraining variables were collected. The socio-economic characteristics of smallholder cocoyam farmers were achieved using descriptive statistics such as percentages, frequencies and means. The allocative efficiency levels of Colocasia and Xanthosoma spp. farmers, determinants of allocative efficiency of Colocasia and Xanthosoma spp. farmers and mean levels of allocative efficiency were realized using the Cobb-Douglas stochastic frontier cost function analytical technique to estimate allocative efficiencies, determinants of allocative efficiencies of the cocoyam farmers and mean levels of allocative efficiency. A 4point Likert type scale was deployed in determining the degree of seriousness of cocoyam production problems.

\section{EMPIRICAL MODEL}

\section{Stochastic frontier cost function model}

In this study, the stochastic frontier cost function model used by Asogwa et al. (2011) and Tijjani and Bakare (2014) was adopted for allocative efficiency analysis. The cost function model is stated as:

$\log C_{1}=\beta_{0}+\beta_{1} \log \mathrm{P}_{1}+\beta_{2} \log \mathrm{P}_{2}+\beta_{3} \log \mathrm{P}_{3}+\beta_{4} \log \mathrm{P}_{4}+$ $\beta_{5} \log \mathrm{Y}_{1}+\mathrm{V}_{\mathrm{i}}+\mathrm{U}_{\mathrm{i}}$

Where:

$\mathrm{C}_{1}=$ Total production cost (Naira)

$\mathrm{P}_{1}=$ Cost of corms (Naira)

$\mathrm{P}_{2}=$ Cost of fertilizer (Naira)

$\mathrm{P}_{3}=$ Cost of organic manure (Naira)

$\mathrm{P}_{4}=$ Cost of labour

$\mathrm{Y}_{1}=$ Total farm output measured $(\mathrm{kg})$

The model for allocative inefficiency is given as: 
$\mathrm{U}_{\mathrm{i}}=\delta_{0}+\delta_{1} \mathrm{Z}_{1}+\delta_{2} \mathrm{Z}_{2}+\delta_{3} \mathrm{Z}_{3}+\delta_{4} \mathrm{Z}_{4}+\delta_{5} \mathrm{Z}_{5}+\delta_{6} \mathrm{Z}_{6}$

Where:

$\mathrm{Z}_{1}=$ Farming experience (years)

$\mathrm{Z}_{2}=$ Educational level of farmers (years)

$\mathrm{Z}_{3}=$ Age of farmers (years)

$\mathrm{Z}_{4}=$ Household size (number)

$\mathrm{Z}_{5}=$ Extension visits

$\mathrm{Z}_{6}=$ Distance to market $(\mathrm{km})$

\section{RESULTS AND DISCUSSION}

From the study, cocoyam production was female dominated (table 1), 69\% were female farmers while $31 \%$ were male farmers. Reasons could be to support the family income and also cater for their large household size. Majority of the farmers precisely $54.5 \%$ fall within the age range of 46-61years, while $37 \%$ were between 30 45 years with a mean of 54years. This indicates that that cocoyam production was carried out by aged farmers who were less receptive to innovations, depended on hired labour and lacked the energy required on the farm. Farmers had household sizes between 1-16 persons and an average of 8 persons. This development implied availability of family labour for the realization of cocoyam production potentials in the area at reduced cost. Majority of the farmers had a formal education: $27.5 \%$ had primary, $35.5 \%$ had secondary and $15 \%$ had tertiary education. This implies openness to innovations that can result in better utilization of resources for output and profit maximization. Majority $(80.5 \%)$ of the farmers had 1-10 years of farming experience, $15.5 \%$ had $10-20$ years and $4.5 \%$ had above 21 years farming experience with a mean of 7.7years experience. This implies that they have not acquired sufficient experience to optimize the use of resources. The study further showed that farmers farm sizes ranged between 0.1-0.9 hactare with majority $(85.5 \%)$ of the farmers having no contact with extension agents during the farming season.

Table.1: Socio-economic characteristics of the cocoyam farmers

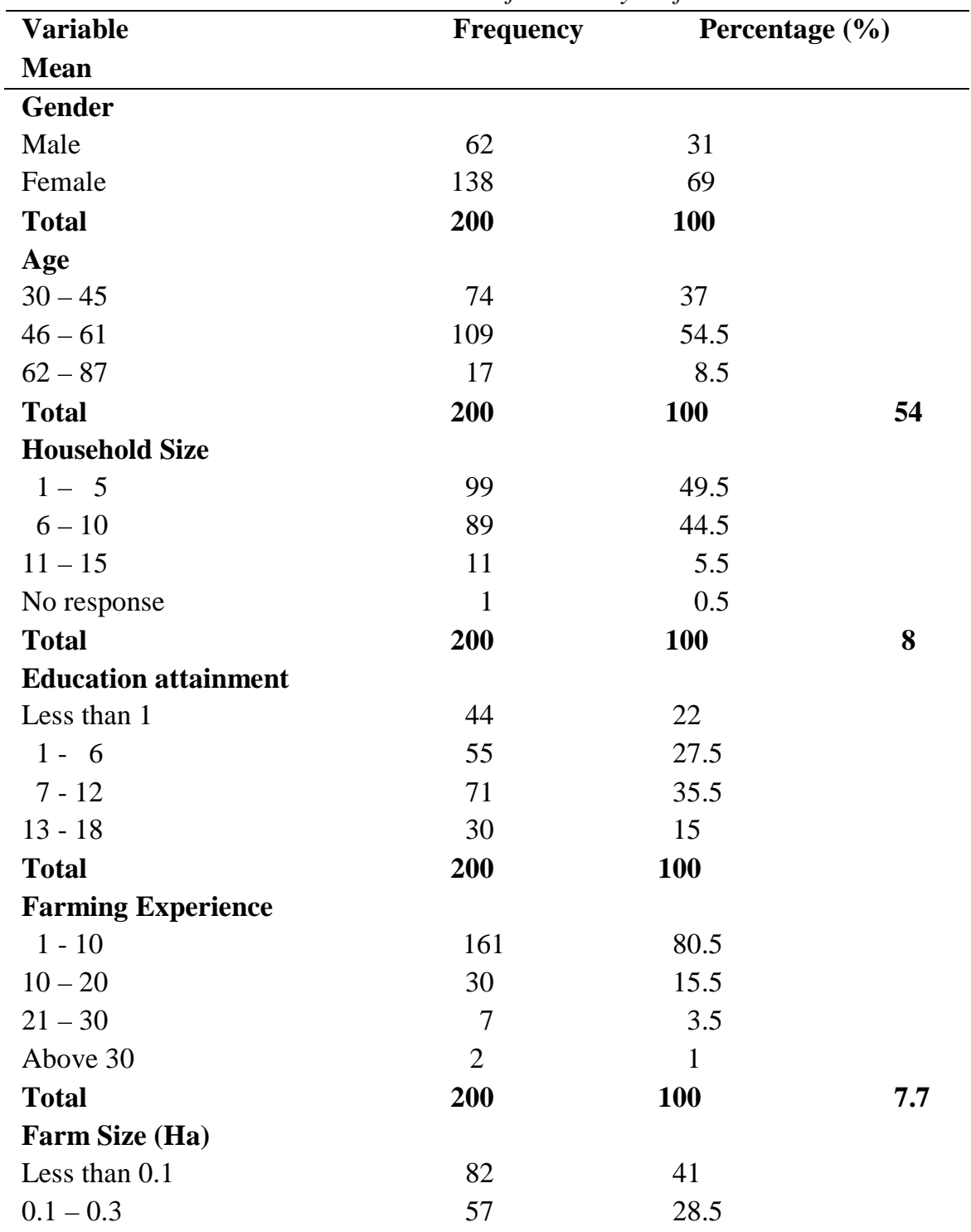




\begin{tabular}{lrc}
\hline $0.4-0.6$ & 33 & 16.5 \\
$0.7-0.9$ & 18 & 9 \\
No response & 10 & 5 \\
Total & $\mathbf{2 0 0}$ & $\mathbf{1 0 0}$ \\
Extension Visit & & \\
No visit & 171 & 85.5 \\
1 & 16 & 8 \\
2 & 10 & 5 \\
3 & 3 & 1.5 \\
Total & $\mathbf{2 0 0}$ & $\mathbf{1 0 0}$ \\
\hline
\end{tabular}

Source: Field survey, 2015.

\section{Allocative Efficiency Levels of the Colocasia and Xanthosoma spp Farmers}

The Cobb-Douglas stochastic frontier cost function approach was used to determine the levels of allocative efficiency of the Colocasia and Xanthosoma spp. farmers in the area and result of the analysis is shown in Table 2. The indices of Allocative Efficiencies (AE) varied substantially among the farmers for the two varieties; ranging between 0.21 and 0.90 with a mean, minimum and maximum $\mathrm{AE}$ of $0.56,0.31$ and 0.86 for Colocasia spp; $0.42,0.22$ and 0.82 for Xanthosoma spp. and a pooled total AE level of 0.52, 0.22 and 0.86 for mean, minimum and maximum for both variety. This implied varying allocative efficiency levels were attained by the farmers and this result is in consonance with findings of Okoye et al. (2006) in Anambra State.

It can be seen in Table 2 that the modal class (41-50) had the higher allocative efficiency than the lowest class (2130) for Colocasia spp.; likewise the modal class (31-40) had the higher allocative efficiency than the lowest class (21-30) for Xanthosoma spp. Similarly, none of the sampled farmers for both varieties attained a $100 \%$ allocative efficiency index. The wide variations in the allocative efficiency estimates is an indication that most of the farmers have not yet achieved optimal resource mix in their production process and there still exists opportunities for improving on their current levels of allocative efficiency.
This result (Table 2) also implied that the average Colocasia spp. farmer would enjoy cost saving of about $34.9 \%(1-0.56 / 0.86)$ to attain the level of the most efficient farmer among the respondents. The most allocatively inefficient farmer will have an efficient gain of $64.0 \%(1-0.31 / 0.86)$ in Colocasia production to attain the efficiency level of most allocatively efficient farmer. On the other hand, if the average Xanthosoma spp. farmer in the sampled area was to achieve AE level of its most efficient counterpart, then the average farmer could realize cost saving of about $48.8 \%$ (1-0.42/0.82). A similar calculation for the most allocatively inefficient farmer shows a cost saving of $73.2 \%(1-0.22 / 0.82)$ to attain efficiency level. On the whole, for an average cocoyam farmer to achieve allocative efficiency, then the farmer would realize a cost saving of about $39.5 \%$ (1$0.52 / 0.86)$ while the most inefficient farmer will have an efficient gain of $74.4 \%(1-0.22 / 0.86)$ to attain allocative efficiency level.

Test of hypothesis about differences in mean allocative efficiency scores between Colocasia and Xanthosoma farmers on Table 3 showed that there was difference in the mean allocative efficiency levels between Colocasia esculenta and Xanthosoma sagittifoluma farmers. Therefore the null hypothesis (hypothesis I), that there is no difference in the allocative efficiency level of the Colocasia and Xanthosoma spp. farmers is rejected and the alternative accepted.

Table.2: Distribition of cocoyam farmers' allocative efficiency scores

\begin{tabular}{lllllll}
\hline Allocative efficiency range (\%) & \multicolumn{2}{c}{ Pooled data } & \multicolumn{2}{c}{ Colocasia } & \multicolumn{2}{c}{ Xanthosoma } \\
& Freq. & \% & Freq. & \% & Freq. & $\%$ \\
\hline $21-30$ & 10 & 5 & 2 & 2 & 8 & 8 \\
$31-40$ & 48 & 24 & 10 & 10 & 38 & 38 \\
$41-50$ & 62 & 31 & 40 & 40 & 22 & 22 \\
$51-60$ & 45 & 22.5 & 26 & 26 & 19 & 19 \\
$61-70$ & 20 & 10 & 12 & 12 & 8 & 8 \\
$71-80$ & 10 & 5 & 6 & 6 & 4 & 4 \\
$81-90$ & 5 & 2.5 & 4 & 4 & 1 & 1 \\
$91-100$ & - & - & - & - & - & - \\
Total & 200 & 100 & 100 & 100 & 100 & 100
\end{tabular}




\begin{tabular}{llll}
\hline Mean & 0.52 & 0.56 & 0.42 \\
Minimum & 0.22 & 0.31 & 0.22 \\
Maximum & 0.86 & 0.86 & 0.82 \\
\hline
\end{tabular}

Source: Computed from survey data, 2015. Notes: Freq. = Frequency. $\%=$ percentage.

Table.3: Test of hypotheses about differences in mean allocative efficiency scores between Colocasia and Xanthosoma farmers

\begin{tabular}{lcccc}
\hline Pair of Variables & MAES (\%) & Difference b/w Pair & t & \\
\hline MAES of Colocasia & 56 & & & \\
MAES of Xanthosoma & 42 & 14 & $3.58^{*}$ \\
\hline
\end{tabular}

Source: Computed from survey data, 2015. Notes: MAES: Mean allocative efficiency score. * Significant $0.05 . \mathrm{P} \leq 1$

\section{Determinants of Allocative Efficiency for Colocasia and Xanthosoma spp \\ Cost Factors}

The maximum likelihood estimates for parameters of the stochastic frontier cost model for the determinants of allocative efficiency for Colocasia and Xanthosoma spp. farmers in the area is presented in Table 3. To check for inefficiency effects, the important parameter of loglikelihood in the half-normal model lambda $(\Lambda)$ was used. Lambda is the ratio of the standard errors of $u$ to $v$. If $\Lambda$ is equal to zero there are no inefficiency effects and all deviations from frontier are due to noise (Aigner, Lovell and Schmidt, 1977). From table 3 Lambda for Colocasia and Xanthosoma spp. were 1.38 and 1.22 respectively showing the existence of inefficiency effects. The estimated values of $y=0.63$ and 0.51 for the two varieties respectively meant that $63 \%$ and $51 \%$ of the total variation in Colocasia and Xanthosoma output were due to allocative inefficiency. These values and their significance confirms the existence of inefficiency and thus the rejection of the null hypothesis II which stated that, allocative efficiency levels attained by Colocasia and Xanthosoma spp. farmers are not significantly influenced by their socio-economic factors namely farming experience, education, age, household size, extension visit and distance and the acceptance of the alternative.

For the estimated cost frontier model, the coefficient of corms and labour were positive and significant at $5 \%$ alpha for Colocasia and Xanthosoma spp. respectively. This implied that the production cost was estimated to be an increasing function of corm price and an increasing function of labour price. For Colocasia the price of labour was highest with a coefficient value of 2.4. This means that farmers spent more on labour and a $1 \%$ increase in labour will lead to a $2.42 \%$ increase on total cost of production of the farmer. Similarly, the cost of corms for Xanthosoma farmers had the highest coefficient taking up a greater proportion of the variable cost inputs and a $1 \%$ increase on corms will lead to $2.64 \%$ increase on total cost of Xanthosoma production.

Table.4: Maximum likelihood estimate of the cocoyam stochastic frontier cost function

\begin{tabular}{|c|c|c|c|c|c|c|c|c|}
\hline \multirow[t]{2}{*}{ Variable } & & \multirow{2}{*}{$\begin{array}{c}\text { Parameter } \\
\text { Coef. }\end{array}$} & \multicolumn{2}{|c|}{ r Pooled data } & \multicolumn{2}{|c|}{ Colocasia } & \multicolumn{2}{|c|}{$\overline{\text { Xanthosoma }}$} \\
\hline & & & $\mathbf{t}$ & Coef. & $\mathbf{t}$ & Coef. & $\mathbf{t}$ & \\
\hline \multicolumn{9}{|l|}{ Cost factor } \\
\hline Constant & $\beta_{0}$ & 3.76 & $7.37 *$ & 2.63 & $3.87 *$ & 2.12 & $3.38 *$ & \\
\hline Corm & $\beta_{1}$ & 0.89 & $5.16^{*}$ & 1.77 & $3.62 *$ & 2.64 & $2.24 *$ & \\
\hline Fertilizer & & $\beta_{2}$ & 0.53 & 1.88 & 0.46 & 1.84 & 0.41 & 1.82 \\
\hline Organic manure & $\beta_{3}$ & 0.41 & 1.79 & 0.62 & 1.86 & 0.53 & 1.76 & \\
\hline Labour & $\beta_{4}$ & 0.76 & $3.42 *$ & 2.42 & $4.26^{*}$ & 2.27 & $2.39 *$ & \\
\hline \multicolumn{9}{|l|}{ Efficiency factor } \\
\hline Constant & $\delta_{0}$ & 17.63 & $4.36^{*}$ & 21.37 & $5.35^{*}$ & 18.46 & $4.91 *$ & \\
\hline FAE & $\delta_{1}$ & 0.26 & $2.84^{*}$ & 0.44 & $4.12 *$ & -0.37 & $-2.86^{*}$ & \\
\hline EDU & $\delta_{2}$ & 0.03 & 0.88 & 0.50 & 1.14 & 0.04 & 0.76 & \\
\hline AGE & $\delta_{3}$ & 0.34 & $3.15^{*}$ & 0.37 & $3.82 *$ & -0.41 & $-2.34 *$ & \\
\hline HHS & $\delta_{4}$ & -0.07 & $-4.36^{*}$ & 0.23 & $3.41 *$ & -0.34 & $-2.67 *$ & \\
\hline
\end{tabular}




\begin{tabular}{llllllrr}
\hline ETV & $\delta_{5}$ & 0.06 & 1.56 & 0.05 & 0.74 & 0.07 & 0.62 \\
DIS & $\delta_{6}$ & 0.08 & 0.66 & -0.04 & -0.83 & -0.09 & -1.12
\end{tabular}

Diagnostic statistic

\begin{tabular}{lrrrr} 
Gamma & $\gamma$ & 0.56 & 0.63 & 0.51 \\
Lambda & $\lambda$ & 1.26 & 1.38 & 1.22 \\
Log likelihood & & 9.75 & 12.68 & 11.04 \\
\hline
\end{tabular}

Source: Computed from survey data, 2015. Notes: Ceof. $=$ Coefficient. $\mathrm{t}=\mathrm{t}$-value. $*$ Significant at 0.05. FAE, EDU, AGE, HHS, ETV and DIS as defined earlier.

\section{Efficiency Factors}

\section{Farmers farming experience}

Table 4 presents result of some socio-economic factors that determine efficiency in the area. Farmers farming experience had positive and negative coefficient respectively for Colocasia and Xanthosoma Spp. farmers and statistically significant at $5 \%$ alpha respectively. The implication was that farmers of Colocasia were able to utilize their farming experience economically while the farmers of Xanthosom were not. Farmers' farming experience is expected to have a positive effect on allocative efficiency and negative on inefficiency (Asogwa et al., 2011), because cost minimizing input combination and revenue maximizing output requires information about technology and market price.

\section{Educational attainment}

The coefficient of education is positive for the two varieties of cocoyam farmers in the study area but, not statistically significant at 5\% alpha level (Table 4). The implication is that this socio-economic factor was uneconomically utilized though majority of the farmers (78\%, Table1) in the study area had formal education. From a priori expectations, education is expected to have positive effect on efficiency because it will enable the farmers to make good use of information about production inputs, thus improving the efficient use of inputs (Khan, 2012). This finding is in disagreement with Okoye et al. (2006) who reported negative and significant coefficient for cocoyam producers in Anambra State. It is also at variance with the findings of Amasa and Olayemi (2000) who reported that increasing years of formal education increases a farmer's level of allocative efficiency.

\section{Age}

The estimated age coefficients were respectively positive and negative for the two variety farmers and also statistically significant at 5\% alpha respectively (Table 4).
The implication for Colocasia farmers was that the older farmers combined experience and managerial skills to attain efficiency while Xanthosoma farmers' may have misallocated resources. The positive coefficient for Colocasia farmers is in agreement with findings of Asogwa et al. (2011) while the negative coefficient for Xanthosoma farmers' is in agreement with findings of Okoye et al. (2006).

\section{Household size}

From Table 4 the estimated household coefficients were positive and negative respectively for farmers of the two different varieties and also statistically significant at $5 \%$ alpha respectively. The a priori expectation is that large household size would increase efficiency by reducing cost on labour. Thus, the positive coefficient for farmers of Colocasia implied the use of household labour in the farm work in order to reduce the number of hired labour and cost which impacted positively on allocative efficiency and this corroborates with the findings of Okoye et al. (2006). The farmers of Xanthosoma on the contrary had negative coefficient which implied that some members of the household may be engaged in other activities and not available for farm work. This is in agreement with the findings of Asogwa et al. (2011).

Constraints to cocoyam production in the area were scarcity of improved high yielding comels, high cost of labour, lack of capital, poor storage facilities, high cost of transportation, use of traditional techniques, diseases and pests' attacks, and scarcity of land. Analysis of the problems according to degree of seriousness as shown in Table 5, showed that scarcity of improved high yielding corms were indicated by the respondents as the most serious constraint to production of the two cocoyam varieties with mean scores of 2.99 and 3.18 for Colocasia and Xanthosoma varieties respectively. Other challenges are indicated as shown on the table.

\section{Table.5: Constraints to cocoyam production in the area}

\begin{tabular}{|c|c|c|c|c|}
\hline Factor & $\begin{array}{l}\text { Colocasia } \\
\text { Mean score }\end{array}$ & Rank & $\begin{array}{l}\text { Xanthosoma } \\
\text { Mean score }\end{array}$ & Rank \\
\hline Scarcity of improved high yielding corms & 2.99 & & 3.18 & \\
\hline High cost of labour & 2.89 & $2^{\text {nd }}$ & 2.80 & $4^{\text {th }}$ \\
\hline
\end{tabular}




\begin{tabular}{|c|c|c|c|c|c|c|c|}
\hline Lack of capital & & 2.82 & & $3^{\mathrm{rd}}$ & & 3.17 & $2^{\text {nd }}$ \\
\hline Lack of storage facilities & 2.78 & & $4^{\text {th }}$ & & 2.77 & $6^{\text {th }}$ & \\
\hline High cost of transportation & 2.71 & & $5^{\text {th }}$ & & 2.92 & $3^{\text {rd }}$ & \\
\hline Use of traditional technique & & 2.57 & & $6^{\text {th }}$ & & 2.53 & $8^{\text {th }}$ \\
\hline Disease and pests & 2.38 & & $7^{\text {th }}$ & & 2.53 & 5 th & \\
\hline Land scarcity & & 2.37 & & $8^{\text {th }}$ & & 2.59 & $7^{\text {th }}$ \\
\hline
\end{tabular}

Source: Field survey, 2015

\section{CONCLUSION AND RECOMMENDATIONS}

Cocoyam production was female dominated, farmers' average age was 54 years, and they had a mean household size of 8 persons, a mean of 7.7 years experience on cocoyam farming. The farmers varied in their allocative efficiency level from the efficiency indices. The inefficiency socio-economic factors of farming experience, age and household size had positive and statistically significant influences on the production cost of Colocasia spp. and negative and statistically significant influences on the production cost of Xanthosoma spp. Farmers of Colocasia were more efficient than the farmers of Xanthosoma spp. Allocative efficiency can be improved for cocoyam (Colocasia and Xanthosoma spp.) through cost savings of $39.5 \%$ and $73.4 \%$ for the efficient and inefficient farmers. Some constraining factors to cocoyam production included scarcity of improved high yielding corms for planying, high cost of labour, lack of capital and lack of storage facilities. It is therefore recommended that farmers should cut down on some of the cost incurring variables like labour and corms for planting through optimizing the use of family labour and growing the corms needed for future planting season. Again, since the ages of cocoyam farmers and farming experience were very significant in the production of cocoyam, it is recommended that the extension agents organize seminars in the Local Government Areas and State levels were young and upcoming cocoyam farmers can be trained and educated by the older farmers so that they can exhibit higher levels of entrepreneurial capabilities and efficiency leading to higher farm output.

\section{REFERENCES}

[1] Adebosin, W. G., Ishola, T. A. \& Aina, S. O. (2011). Evaluation of government agricultural policies in Nigeria: The way forward. Proceedings of the $12^{\text {th }}$ Annual National Conference of the Nigerian Association of Agricultural Economists, Benin, Edo State. (pp. 6-13).

[2] Adelekan, B. A. (2012). An evaluation of the global potential of cocoyam (colocasia and xanthosoma species) as an energy crop. British Journal of Applied Science \& Technology, 2(1), 1-15.

[3] Aigner, D., Lovell, C. A. K. \& Schmidt, P. (1977). Formulation and estimation of stochastic frontier production function models. Journal of Econometrics, 6, 21-37.

[4] Ajao, A. O., Ogunniyi, L. T. \& Adepoju, A. A. (2012). Economic efficiency of soybean production in Ogo-Oluwa local government area of Oyo State, Nigeria.American Journal of Experimental Agriculture, 2(4), 667-679.

[5] Ajie, E. N., Chidebelu, S.A.N.D. \& Achike, A. I. (2015). Marketing of cocoyam in Rivers State, Nigeria. (doctoral dissertation). University of Nigeria, Nsukka.

[6] Amasa, P. S. \& Olayemi, J. K. (2000). The influence of education and extension contact on food crop production in Gombe State, Nigeria. Journal of Agribusiness and Rural Development, 1, 80-90

[7] Asadu, A. N. (2006). Causes of decline in cocoyam production among farmers in Enugu state. Department of agricultural extension, University of Nigeria Nsukka, 2.

[8] Asogwa, B. C., Ihemeje, J. C. \& Ezihe, J. A. C. (2011). Technical and allocative efficiency analysis of Nigerian rural farmers: Implication for poverty reduction. Agricultural Journal, 6(5), 243251. DOI: 10.3923/aj.

[9] Bifarin, J. O., Alimi, T., Baruwa, O. I. \& Ajewole, O. C. (2010). Determinant of technical, allocative and economic efficiencies in the plantain (musa spp.) production industry, Ondo State, Nigeria. (pp. 199-209).

[10] Echebiri, R. N. (2004). Socio-economic factors and resource allocation in cocoyam production in Abia State, Nigeria: A case study. Journal of Sustainable Tropical Agricultural Research, 9, 6973.

[11]Edoumiekumo, S. G., Karimo, T. M. \& Tombofa, S. S. (2014). Determinants of households' income poverty in the South South geopolitical zone of Nigeria. Journal of Studies in Social Sciences, 9(1), 101-115.

[12]Food and Agricultural Organization, FAO (2005). Yearbook of Agricultural Statistics. Food and Agricultural Organization of the United Nations, Rome.

[13] Njoku, P. C. and Olomola, A. S. (2011). 50 years of post-independence development in Nigeria: the 
case of agriculture and food security chapter in Nigeria at 50. NISER, Ibadan.

[14] Okoye, B. C., Asumugha, G. N., Okeke, C. A., Tanko, L. \& Onyenweaku, C. E. (2008). Economic assessment of the trading of cocoyam production in Nigeria. 1960/1961- 2003- 2006.

[15] Onwubuya, E. A. \& Ajani, E. N. (2012). Strategies for improving production and processing of cocoyam among women farmers in Anambra State, Nigeria. Universal Journal of Education and General Studies, 1(6), 169-173.

[16] Onyeka, J. (2014). Status of Cocoyam (Colocasia esculenta and Xanthosoma spp) in West and Central Africa: Production, Household Importance and the Threat from Leaf Blight. Lima (Peru). CGIAR Research Program on Roots, Tubers and Bananas (RTB).

[17] Ozor, M. U. (2013). Comparative analysis of the profitability of two cocoyam varieties in

Enugu West agricultural zone of Enugu State. (Master's thesis). Anambra State University, Igbariam, Nigeria.

[18] Tijjani, A. \& Bakari, U. M. (2014). Determinants of allocative efficiency of rain-fed rice production in Taraba State, Nigeria. European Scientific Journal, 10(33), 220-229.

[19] Ugbajah, M. O. (2013). Enhancing income through cocoyam production, processing and consumption patterns in Dunukofia local government area of Anambra State, Nigeria. Greener Journal of Social Sciences, 3(6), 334 - 339. 